Article

\title{
Separation of Small DNAs by Gel Electrophoresis in a Fused Silica Capillary Coated with a Negatively Charged Copolymer
}

\author{
Tomoka Nakazumi and Yusuke Hara * \\ Research Institute for Sustainable Chemistry, National Institute of Advanced Industrial Science \\ and Technology (AIST), Tsukuba Central 5, 1-1-1 Higashi, Tsukuba, Ibaraki 305-8565, Japan; \\ nakazumi.t@aist.go.jp \\ * Correspondence: y-hara@aist.go.jp; Tel.: +81-29-861-9318
}

Received: 13 May 2017; Accepted: 4 September 2017; Published: 20 September 2017

\begin{abstract}
Active development of compact analytical instruments suitable for point-of-care testing (POCT) requires optimization of existing methods. To aid the development of capillary gel electrophoresis instruments for $\mathrm{POCT}$, we attempted to separate polymerase chain reaction products (small DNAs) using a short, fused silica capillary coated with an acrylamide (AM)/acrylic acid (AA) copolymer (poly(AM-co-AA)). To realize the high capability of this capillary to separate small DNAs, the magnitude of electroosmotic flow (EOF) was controlled by varying the content of negatively charged AA in the copolymer, which significantly affected the separation ability. At an AA content $\geq 3.75 \mathrm{~mol} \%$, sample DNAs could not be injected into the copolymer-coated capillary owing to strong EOF, whereas a $100 \mathrm{bp}$ DNA ladder sample was successfully separated at an AA content of $\leq 3.5 \mathrm{~mol} \%$, showing that even slight AA content variations impact DNA flow. EOF values measured using a neutral coumarin 334 solution suddenly decreased at an AA content of $3.5 \mathrm{~mol} \%$ relative to those at an AA content of $\geq 3.75 \mathrm{~mol} \%$. Theoretical plate values revealed that an AA content of $2.75 \mathrm{~mol} \%$ was optimal for separating ladder DNAs with sizes $\geq 600 \mathrm{bp}$. Hence, EOF control achieved by varying the amount of negatively charged AA in the poly(AM-co-AA) coating can promote further development of short capillaries for POCT applications.
\end{abstract}

Keywords: DNA; polymerase chain reaction (PCR); electroosmotic flow (EOF); copolymer; capillary gel electrophoresis

\section{Introduction}

Compact analytical instruments suitable for point-of-care testing (POCT) have been actively developed worldwide, as exemplified by small devices for immediate bedside examination that rely on the (quantitative) polymerase chain reaction ((q)PCR) [1-4]. These techniques can enhance the quantification of specific DNA sequences, with the corresponding analytical results being applicable to disease diagnosis (e.g., influenza) [5-8], environmental monitoring, and microbiological food analysis [9-11]. In the case of qPCR, the target gene fragment is monitored by fluorescence spectroscopy, allowing the quantitative analysis of amplified small DNAs. However, this method cannot discriminate between specific and non-specific PCR products, implying that the obtained results can include a contribution from the latter. Slab gel electrophoresis (SGE), frequently used to identify and quantify PCR products, also cannot clearly discriminate between specific and non-specific PCR products owing to the wide peak bandwidth observed in the gel. Compared to SGE, capillary gel electrophoresis (CGE) requires smaller sample volumes and is capable of faster analysis and higher resolution [12-17]. The capillaries used for CGE, which have internal diameters of 25-100 $\mu \mathrm{m}$, allow the use of a higher voltage relative to that for SGE owing to better Joule heat dissipation. As CGE can clearly identify 
non-specific PCR products owing to the small bandwidth of the observed peaks, we adopted it as a method for PCR product analysis and are currently developing the corresponding compact equipment for POCT. In CGE, the separation time decreases with increasing applied voltage, owing to increasing DNA flow speed in the capillary [18]. Additionally, an electroosmotic flow (EOF) exists inside the capillary, opposing DNA flow and blocking DNA insertion. Mathematical analysis suggests that a constant EOF magnitude contributes to the robustness and durability of the CGE process, implying that EOF control is strongly required for the efficient separation of small DNAs [19].

In previous studies, EOF control was achieved by changing the wall surface charge density $\left(\sigma^{*}\right)$ and solution viscosity $(\eta)$. Generally, the EOF can be reduced by coating the capillary surface with polymers such as polyacrylamide [20,21], polyvinylpyrrolidinone (PVP) [22], and polyethylene glycol (PEG) [23-27]. On the other hand, EOF control has previously been achieved by decreasing the double layer thickness, owing to an increase in the electrolyte concentration or reducing the permittivity of the buffer solution [28,29]. However, these approaches are limited by increased Joule heating in the capillary at increased electrolyte concentrations. Alternatively, EOF control can be achieved through buffer viscosity changes by utilizing hydrophilic polymers [30-32].

Herein, effective EOF modulation for small DNA separation was achieved by controlling the surface charge on the capillary wall using a coating of an uncharged polymer (polyacrylamide (poly(AM)) modified with a negatively charged component (acrylic acid (AA)), which improved the CGE separation ability. As the primary objective of this research was to develop a compact analytical instrument for POCT, a short capillary (total length: $15 \mathrm{~cm}$, effective length: $7.5 \mathrm{~cm}$ ) was used to enable the application of this method in small devices. CGE measurements performed using the copolymer-coated capillary revealed the effect of AA content on the separation of small DNAs, allowing the optimal copolymer composition to be determined.

\section{Materials and Methods}

\subsection{Capillary Coating Procedure}

After washing the capillary with $1 \mathrm{~N} \mathrm{NaOH}$ (15 min), water (15 min), and methanol (15 min), it was flushed with $20 \mathrm{~mL}$ of an aqueous solution containing 3-methacryloxypropyltrimethoxysilane (Shin-Etsu Chemical, Tokyo, Japan; $80 \mu \mathrm{L}$ ), methanol $(1 \mathrm{~mL}$ ), and one drop of acetic acid for $2 \mathrm{~h}$ at room temperature, which resulted in covalent bonding of the silane to the capillary glass wall. The capillary was washed with methanol and water, and monomer solutions were flowed for $2 \mathrm{~h}$ at room temperature. The monomer solutions were prepared by dissolving acrylamide (AM) and acrylic acid (AA) monomers, ammonium persulfate (APS; $20 \mathrm{mg}$ ), and $N, N, N^{\prime}, N^{\prime}$-tetramethylethylenediamine (TEMED; $20 \mu \mathrm{L}$ ) in $20 \mathrm{~mL}$ of water, followed by deoxygenation for $30 \mathrm{~min}$ with nitrogen gas. The total monomer weight equaled $0.7 \mathrm{~g}$, with the used AA/AM compositions shown in Table 1 . After exposure to the monomer solutions, the fused silica capillaries were rinsed with water.

Table 1. Compositions of monomer solutions.

\begin{tabular}{ccc}
\hline & Acrylic Acid Monomer (mol \%) & Acrylamide Monomer (mol \%) \\
\hline 1 & 100.00 & 0.00 \\
2 & 10.00 & 90.00 \\
3 & 6.00 & 94.00 \\
4 & 4.00 & 96.00 \\
5 & 3.75 & 96.25 \\
6 & 3.50 & 96.50 \\
7 & 3.00 & 97.00 \\
8 & 2.75 & 97.25 \\
9 & 2.50 & 97.50 \\
10 & 2.00 & 98.00 \\
11 & 1.00 & 99.00 \\
12 & 0.00 & 100.00 \\
\hline
\end{tabular}




\subsection{Instrumentation}

All CGE experiments were performed using a self-built instrument comprising a high-voltage power supply (HJPQ-10P3, Matsusada, Shiga, Japan) and a microscope with epi-illumination (IX73, Olympus, Tokyo, Japan) (Figure 1). The conjugate of SYBR Green II and DNA was detected using mercury lamp radiation passed through an optical filter (U-FBWA, Olympus, Tokyo, Japan) as an excitation source (460-495 nm). The induced fluorescence radiation of DNA samples was collected by a $60 \times$ objective lens (UPlanFLN, Olympus, Tokyo, Japan) and detected using a photomultiplier tube (PMT; H8249-101, Hamamatsu Photonics, Hamamatsu, Japan). In addition, the PMT signal was digitized using a National Instrument NI USB-6341 digitizer (National Instruments, Austin, TX, USA). LabVIEW software (National Instruments, Austin, TX, USA) was used to control the applied voltage and acquire digital data. Fused silica capillaries with a $75 \mu \mathrm{m}$ diameter (Polymicro Technologies, Phoenix, AZ, USA) were cut to lengths of $15 \mathrm{~cm}$. The thus-obtained capillaries had an effective length of $7.5 \mathrm{~cm}$. DNA sample injection was performed by applying a voltage of $1.5 \mathrm{kV}$ for $1 \mathrm{~s}$, with separation subsequently conducted at a field strength of $100 \mathrm{~V} / \mathrm{cm}$.

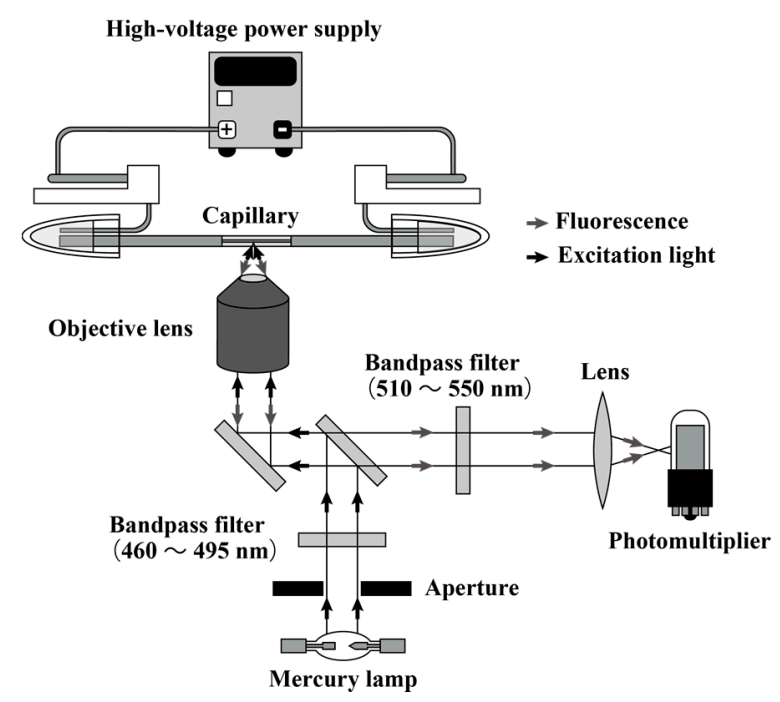

Figure 1. Schematic illustration of the capillary gel electrophoresis (CGE) instrument.

\subsection{Chemicals}

To prepare the running buffer, $5 \times$ tris(hydroxymethyl)aminomethane (Tris)-borateethylenediaminetetraacetic acid (EDTA) buffer (TBE buffer) ( $44.5 \mathrm{mM}$ Tris, $44.5 \mathrm{mM}$ borate, $1.0 \mathrm{mM}$ EDTA, $\mathrm{pH}$ 8.3) (Nippon Gene, Tokyo, Japan) was diluted to $0.5 \times$ with ultra-pure water. Hydroxyethyl cellulose (HEC) with an average molecular weight of $1,300,000$ was selected as a sieving polymer. The sieving polymer solution contained $0.5 \mathrm{wt} \%$ HEC solution, $0.5 \times$ TBE buffer, and $2 \times$ SYBR Green II (Takara Bio, Kusatsu, Japan). A 100 bp DNA ladder (Takara Bio, Kusatsu, Japan) comprising 11 double-stranded fragments $(100,200,300,400,500,600,700,800,900,1000$, and $1500 \mathrm{bp})$ was selected as the measurement target, and its stock solution $(130 \mu \mathrm{g} / \mathrm{mL})$ was diluted $10 \times$ and injected into the CGE apparatus.

\subsection{EOF Measurements}

The EOF measurements were conducted via fluorescence detection in $0.5 \mathrm{wt} \% \mathrm{HEC}$ in $0.5 \times$ TBE buffer. Neutral coumarin 334 in $0.5 \times$ TBE buffer solution was selected as a fluorescence marker. In this measurement, the neutral marker was injected into the capillary by applying a voltage of $1.5 \mathrm{kV}$ for $1 \mathrm{~s}$ from the cathode, with subsequent application of an electric field of $100 \mathrm{~V} / \mathrm{cm}$. 


\section{Results and Discussion}

Figure 2 schematically illustrates the capillary coating procedure used in this study. First, the capillary surface was thoroughly washed and grafted with the silane coupling agent required to chemically bind the copolymer. Grafting was then performed by flushing the capillary with an aqueous solution of the silane coupling agent containing methanol and one drop of acetic acid at room temperature for $2 \mathrm{~h}$. In the next step, the grafted silane and AM/AA monomers were copolymerized by flowing the monomer solution through the capillary at room temperature. The monomer solution contained TEMED as a reaction accelerator to allow facile room-temperature copolymerization.

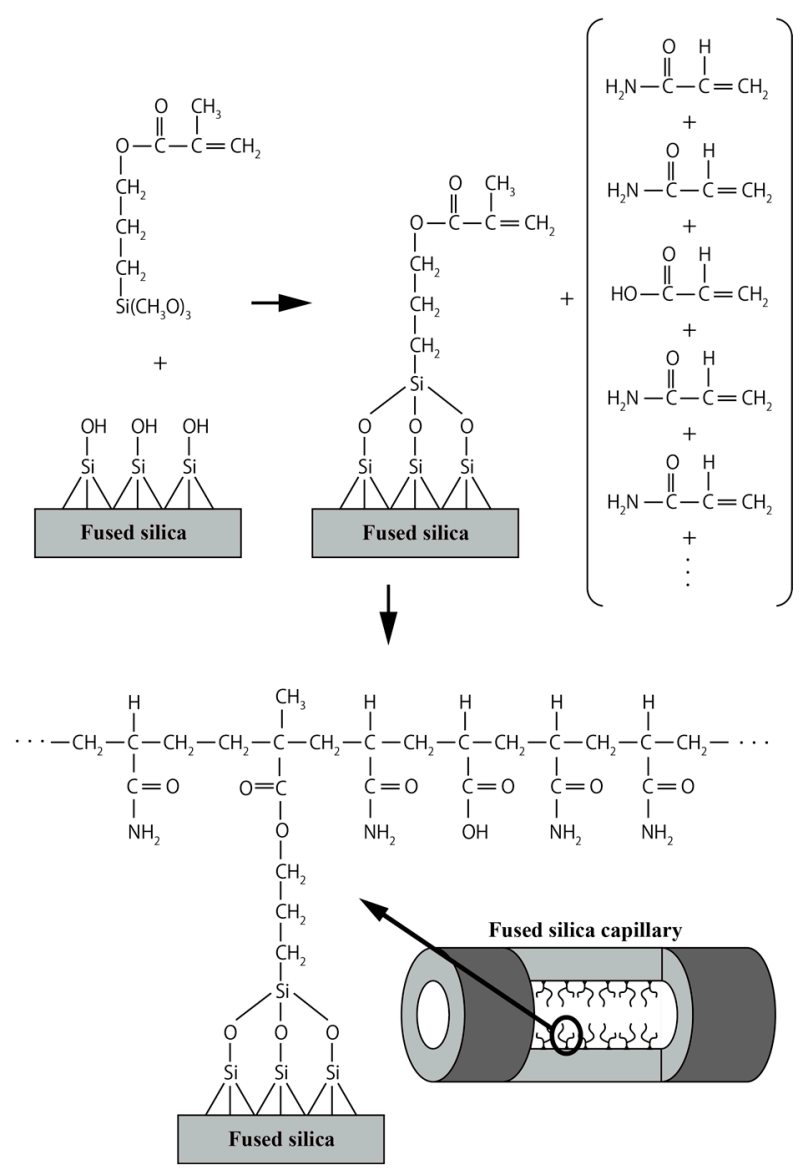

Figure 2. Schematic illustration of the coating procedure.

Figure 3 shows that the $100 \mathrm{bp}$ DNA ladder sample could be efficiently separated using a $100 \mathrm{~mol} \%$ poly(AM) coating owing to effective EOF suppression by the uncharged polymer. However, when an untreated washed fused silica capillary was used, no CGE peaks were observed, as DNA samples could not be inserted into the capillary owing to the opposite direction of the EOF. This finding demonstrated that untreated fused silica capillaries cannot be used for the separation of small DNAs by CGE owing to the EOF disturbing the DNA flow. As shown in Figure 3, peaks with maxima between 600 and 1500 bp were less efficiently separated than those with maxima between 100 and $500 \mathrm{bp}$, which complicated DNA separation by allowing peaks of DNA strands with lengths between 600 and $1500 \mathrm{bp}$ to overlap. If the separation efficiency in this DNA length region could be increased without changing the capillary length, the modified capillary would be capable of separating a wider range of DNA samples and thus be suitable for use in compact POCT equipment. Herein, DNA peak separation in this range was improved by adjusting the AA content of the poly(AM-co-AA) coating on the capillary wall. 


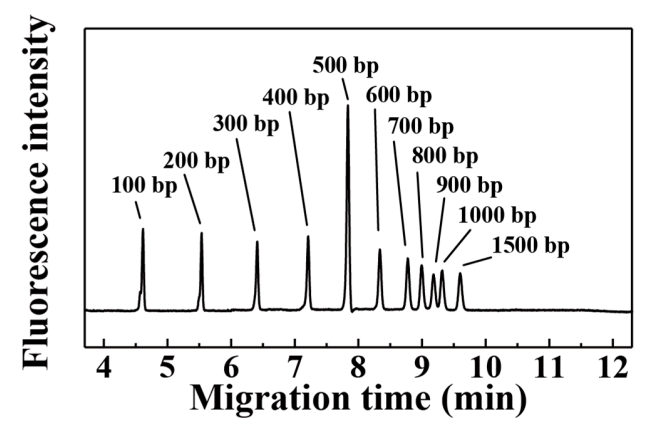

Figure 3. Separation of DNA samples by CGE using a capillary coated with $100 \mathrm{~mol} \%$ polyacrylamide.

Figure 4 illustrates the method utilized to increase the DNA separation ability during CGE, featuring the use of strength-adjusted EOF to decrease the DNA flow speed. To explain our EOF control strategy, we use the numerical formula defining electroosmotic mobility $\left(\mu_{\mathrm{eo}}\right)[21,33]$ :

$$
\mu_{\mathrm{eo}}=-\frac{\epsilon \psi_{0}}{\eta}
$$

where $\psi_{0}$ denotes the electrical potential of the capillary/solution interface and $\varepsilon$ is the electrical permittivity of the CGE solvent. Additionally, $\sigma^{*}$ can be expressed as

$$
\sigma^{*}=\epsilon \kappa \psi_{0},
$$

where $\kappa$ is the capillary double layer thickness. Thus, electroosmotic mobility can be expressed in terms of surface charge density and double layer thickness:

$$
\mu_{\mathrm{eo}}=\frac{\sigma^{*} \kappa^{-1}}{\eta}
$$

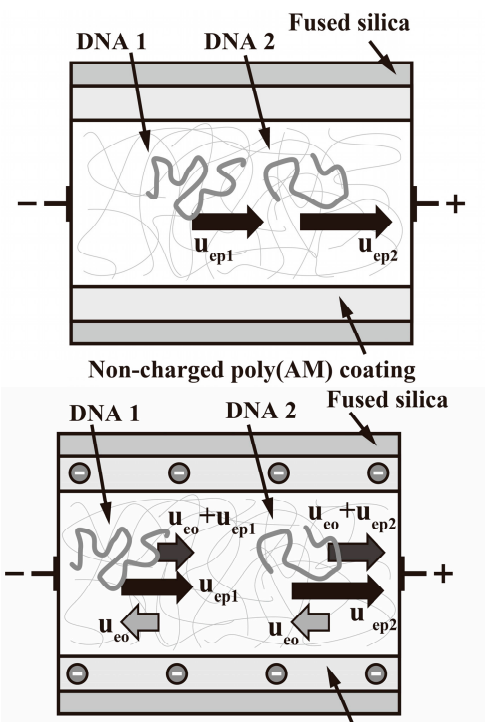

DNA length

DNA $1>$ DNA 2

$\mathrm{u}_{\mathrm{ep} 1}:$ Electropholitic migration velocity of DNA 1

$\mathrm{u}_{\mathrm{ep} 2}:$ Electropholitic migration velocity of DNA 2

DNA length

DNA $1>$ DNA 2

$u_{\mathrm{ep} 1}:$ Electropholitic migration velocity of DNA 1

$\mathbf{u}_{\mathrm{ep} 2}:$ Electropholitic migration velocity of DNA 2

$\mathbf{u}_{\mathrm{ee}}:$ Velocity of electroosmotic flow

Negatively charged poly-(AM-co-AA) coating

Figure 4. Method used to enhance CGE peak separation of DNA samples.

The EOF strength was controlled utilizing a slightly negatively charged polymer coating, determined by the negative charge of the capillary wall (Equation (3)). To control this charge, we evaluated the influence of AA content in the poly(AM-co-AA) coating on separation performance. 
Utilization of strength-adjusted EOF allowed the DNA flow speed to be decreased, which increased the flow speed difference between DNAs of different lengths and thus increased the corresponding detection time interval.

Figure 5 shows the results of separating the $100 \mathrm{bp}$ DNA ladder sample using capillaries coated with poly(AM-co-AA). No CGE signals were observed in the case of poly(AM-co-AA) with 3.75-100 mol \% AA (see Figure 5a,b), whereas successful separation was observed for an AA content of $3.5 \mathrm{~mol} \%$ (Figure $5 \mathrm{c}$ ). These results indicate that AA contents $\geq 3.75 \mathrm{~mol} \%$ prevented DNA injection by inducing a strong EOF that opposed the movement of negatively charged DNA toward the anode. An AA content of $3.5 \mathrm{~mol} \%$ allowed clear CGE separation of the $100 \mathrm{bp}$ DNA ladder sample (Figure 5c), indicating that a difference of only $0.25 \mathrm{~mol} \%$ significantly enhanced the separation process. In other words, we clarified that the maximal AA content of the poly(AM-co-AA) coating allowing the separation of small DNAs is $3.5 \mathrm{~mol} \%$.

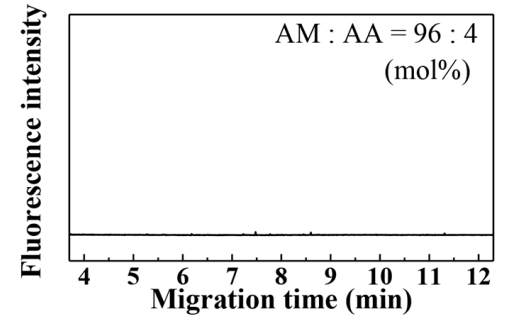

(a)

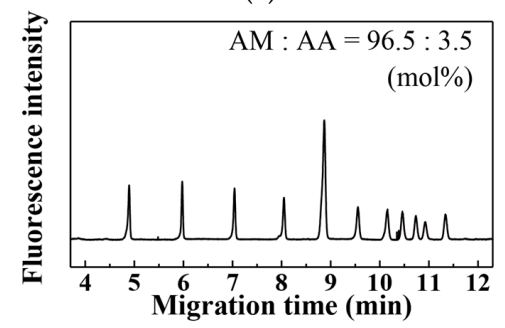

(c)

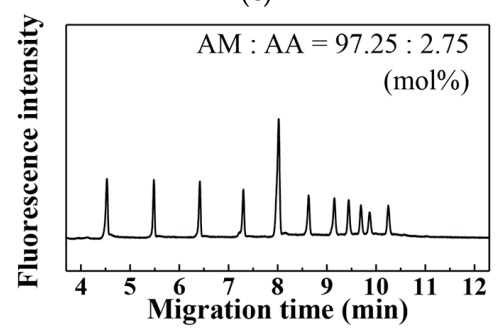

(e)

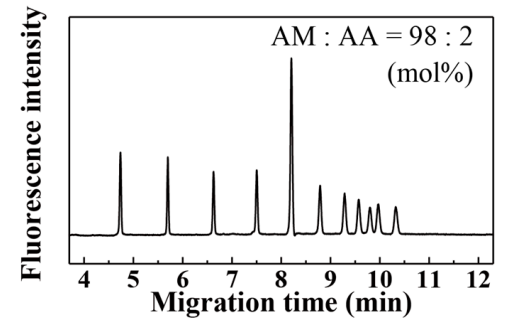

(g)

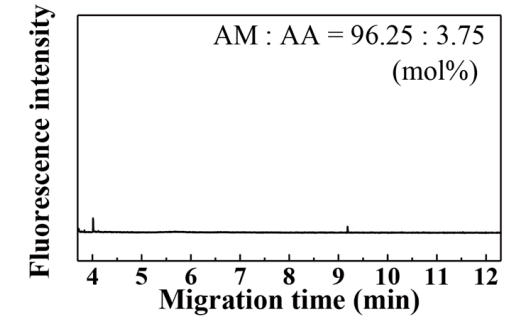

(b)

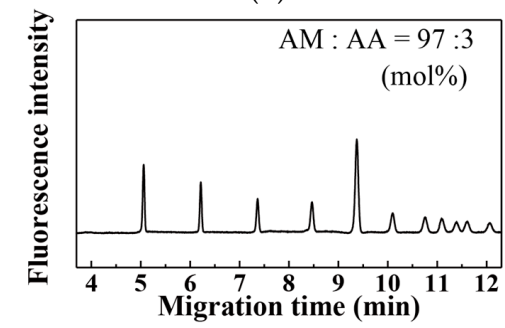

(d)

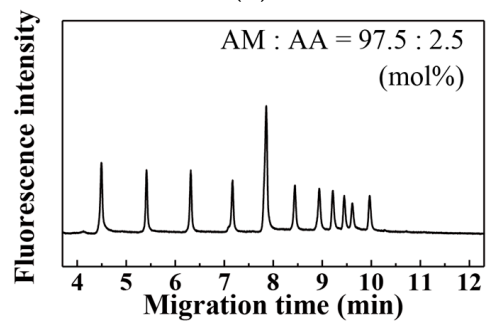

(f)

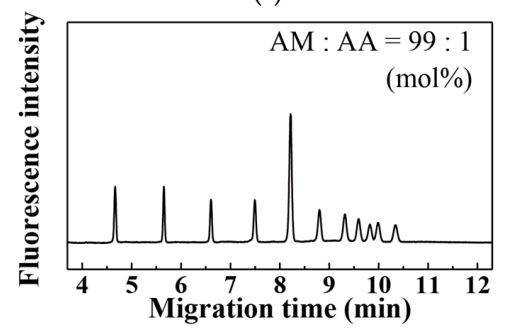

(h)

Figure 5. DNA separation by CGE for poly(AM-co-AA) coating with various AA contents: (a) 4 mol \%; (b) $3.75 \mathrm{~mol} \%$; (c) $3.5 \mathrm{~mol} \%$; (d) $3 \mathrm{~mol} \%$; (e) $2.75 \mathrm{~mol} \%$; (f) $2.5 \mathrm{~mol} \%$; (g) $2 \mathrm{~mol} \%$; and (h) $1 \mathrm{~mol} \%$.

Figure 6 shows the relationships between DNA mobility and DNA size for different AA contents in the poly(AM-co-AA) coating, revealing that the mobilities observed for the poly(AM) coating are higher than those observed for the poly(AM-co-AA) coatings. In particular, the mobilities observed 
for the poly(AM-co-AA) coatings with 3.0 and $3.5 \mathrm{~mol} \% \mathrm{AA}$ are lower than those observed for AA contents $\leq 2.75 \mathrm{~mol} \%$. This result demonstrated that increasing the AA content of the poly(AM-co-AA) coating increased the EOF strength and reduced DNA mobility.

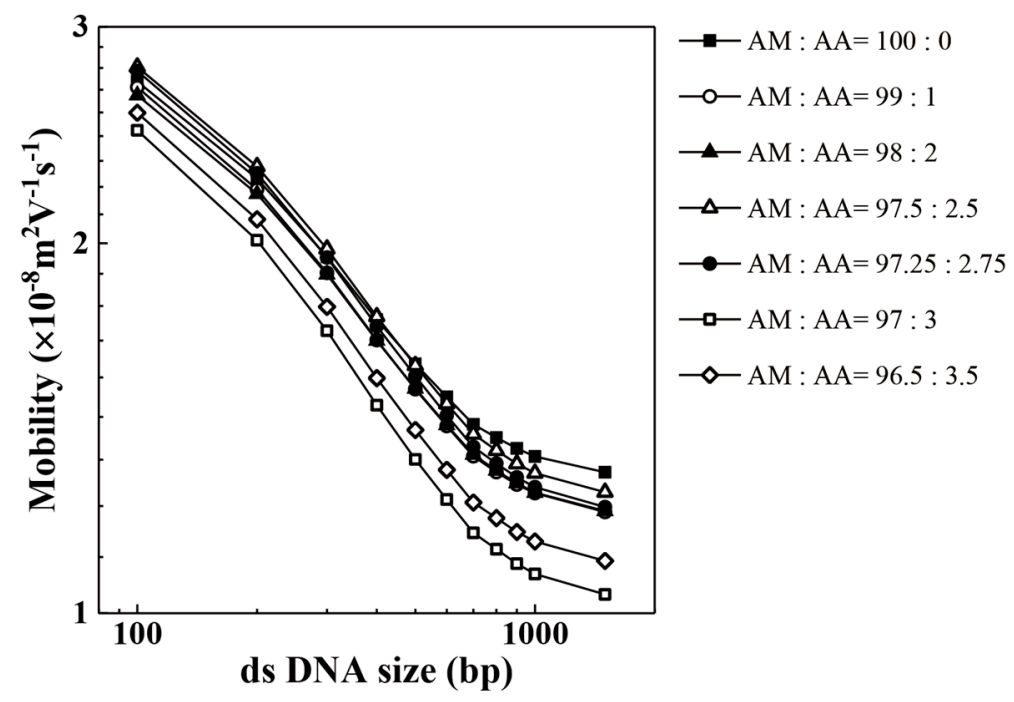

Figure 6. Relationships between double-stranded DNA (ds DNA) mobility and size for poly(AM-co-AA) coatings with different AA contents.

Figure 7 and Table 2 show the relationships between theoretical plate values and DNA size for poly(AM-co-AA) coatings with different AA contents. As shown in this figure, the maximum theoretical plate values for the separation of DNAs with sizes of $\geq 600 \mathrm{bp}$ in the $100 \mathrm{bp}$ DNA ladder were obtained with an AA content of $2.75 \mathrm{~mol} \%$ in the poly(AM-co-AA) coating. On the other hand, the $2.0 \mathrm{~mol} \%$ AA coating afforded higher theoretical plate values for DNA sizes $\leq 500 \mathrm{bp}$, with the exception of $100 \mathrm{bp}$. This trend indicated that an AA content of $2.75 \mathrm{~mol} \%$ is best suited for the separation of DNAs with sizes of $\geq 600 \mathrm{bp}$ in the $100 \mathrm{bp}$ DNA ladder when utilizing a short capillary.

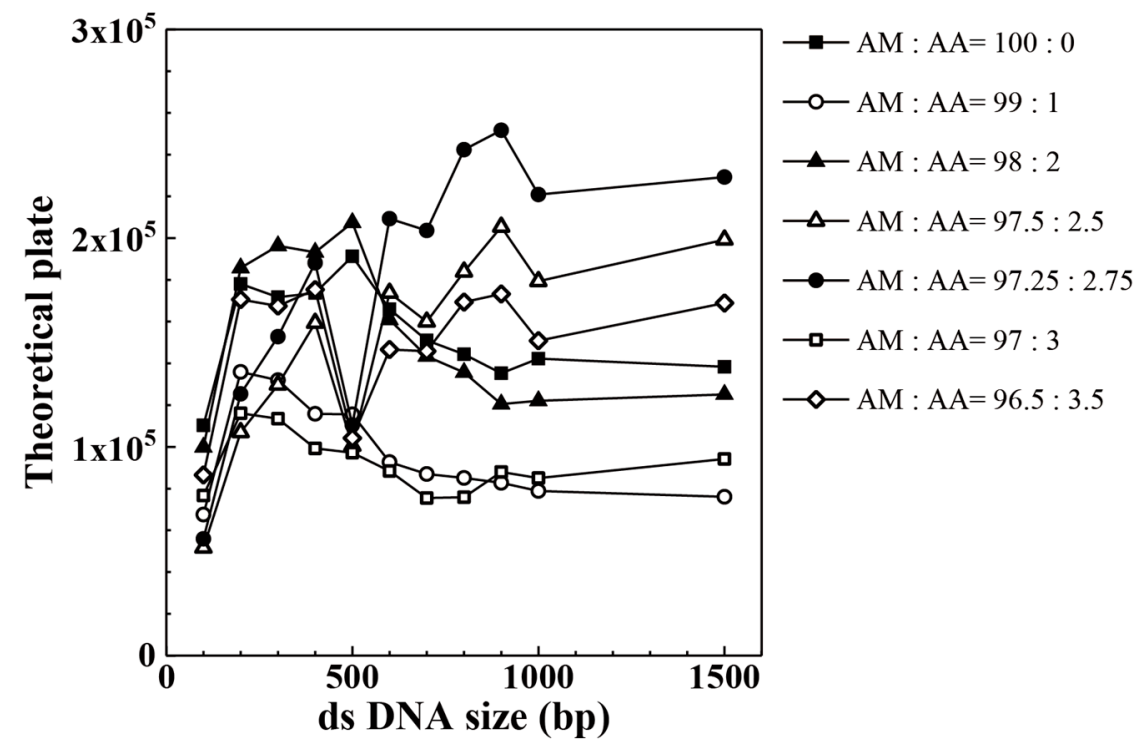

Figure 7. Relationship between theoretical plate values and the size of ds DNA for poly(AM-co-AA) coatings with different AA contents. 
Table 2. Theoretical plate values obtained for DNAs of different sizes for poly(AM-co-AA) coatings with different AA contents.

\begin{tabular}{ccccccc}
\hline AM:AA & $\mathbf{1 0 0} \mathbf{b p}$ & $\mathbf{2 0 0} \mathbf{b} \mathbf{p}$ & $\mathbf{3 0 0} \mathbf{b p}$ & $\mathbf{4 0 0} \mathbf{b p}$ & $\mathbf{5 0 0} \mathbf{b p}$ & $\mathbf{6 0 0} \mathbf{b p}$ \\
\hline $96.50: 3.50$ & 86,563 & 170,584 & 167,479 & 175,338 & 104,213 & 146,590 \\
$97.00: 3.00$ & 76,663 & 116,110 & 113,523 & 99,269 & 97,206 & 88,442 \\
$97.25: 2.75$ & 55,909 & 125,373 & 152,776 & 188,159 & 110,435 & 209,298 \\
$97.50: 2.50$ & 51,669 & 107,010 & 129,720 & 159,323 & 100,413 & 173,799 \\
$98.00: 2.00$ & 99,862 & 185,749 & 196,343 & 193,207 & 207,447 & 160,890 \\
$99.00: 1.00$ & 67,556 & 135,935 & 131,942 & 115,842 & 115,566 & 92,687 \\
$100.00: 0.00$ & 110,291 & 178,095 & 171,701 & 173,681 & 191,241 & 166,005 \\
\hline AM:AA & $\mathbf{7 0 0} \mathbf{b} \mathbf{p}$ & $\mathbf{8 0 0} \mathbf{b} \mathbf{p}$ & $\mathbf{9 0 0} \mathbf{b p}$ & $\mathbf{1 0 0 0} \mathbf{b p}$ & $\mathbf{1 5 0 0} \mathbf{b p}$ & \\
\hline $96.50: 3.50$ & 145,837 & 169,387 & 173,275 & 150,837 & 168,889 & \\
$97.00: 3.00$ & 75,506 & 75,888 & 87,953 & 85,048 & 94,195 & \\
$97.25: 2.75$ & 203,659 & 242,351 & 251,685 & 220,883 & 229,262 & \\
$97.50: 2.50$ & 159,915 & 183,884 & 205,394 & 179,339 & 199,214 & \\
$98.00: 2.00$ & 143,360 & 135,640 & 120,527 & 122,062 & 125,090 & \\
$99.00: 1.00$ & 86,982 & 85,101 & 82,764 & 78,894 & 76,054 & \\
$100.00: 0.00$ & 151,064 & 144,323 & 135,263 & 142,263 & 138,389 & \\
\hline
\end{tabular}

Table 3 gives the EOF values obtained by utilizing a solution of neutral coumarin 334 . For AA contents $<3.50 \mathrm{~mol} \%$, the EOF values suddenly decrease relative to those for AA contents $\geq 3.75 \mathrm{~mol} \%$. As shown in Figure 5, for poly(AM-co-AA) coatings with AA contents $\leq 3.50 \mathrm{~mol} \%$, the $100 \mathrm{bp}$ DNA ladder sample can be separated clearly by the CGE. On the contrary, no CGE signals are observed in the case of poly(AM-co-AA) coatings with AA contents of 3.75-100 mol \%. Thus, the AA content at which a large change in the EOF value was observed is consistent with the AA content at which $100 \mathrm{bp}$ DNA ladder samples could not be separated. Moreover, the EOF value of poly(AM) was significantly lower than that of the poly(AM-co-AA) coatings, which indicated that a very small amount of AA significantly affects the EOF in the CGE process.

Table 3. Electroosmotic flow (EOF) values obtained for poly(AM-co-AA) coatings with different AA contents by using a solution of neutral coumarin 334 .

\begin{tabular}{|c|c|c|}
\hline AM:AA (mol \%) & Migration Time for Neutral Marker (min) & EOF $\left(\times 10^{-8} \mathrm{~m}^{2} \cdot \mathrm{V}^{-1} \cdot \mathrm{s}^{-1}\right)$ \\
\hline $0.00: 100.00$ & 2.69 & 4.65 \\
\hline $90.00: 10.00$ & 2.69 & 4.65 \\
\hline $94.00: 6.00$ & 2.80 & 4.46 \\
\hline $96.00: 4.00$ & 2.89 & 4.33 \\
\hline $96.25: 3.75$ & 2.76 & 4.53 \\
\hline $96.50: 3.50$ & 44.20 & 0.28 \\
\hline $97.00: 3.00$ & 31.29 & 0.40 \\
\hline $97.25: 2.75$ & 48.73 & 0.26 \\
\hline $97.50: 2.50$ & 58.34 & 0.21 \\
\hline $98.00: 2.00$ & 49.96 & 0.25 \\
\hline $99.00: 1.00$ & 54.55 & 0.23 \\
\hline 100.00:0.00 & 173.51 & 0.07 \\
\hline
\end{tabular}

\section{Conclusions}

We demonstrated that the EOF can be effectively used to control DNA flow in a CGE capillary during separation. Optimization of the AA content of the poly(AM-co-AA) capillary coating revealed that DNA samples could not be injected at AA contents above $3.75 \mathrm{~mol} \%$, owing to the strong EOF opposing DNA flow. Conversely, AA contents below $3.5 \mathrm{~mol} \%$ allowed the $100 \mathrm{bp}$ DNA ladder to be clearly separated. The EOF values measured using a solution of neutral coumarin 334 were significantly lower at AA contents below $3.5 \mathrm{~mol} \%$, compared to those at AA contents 
above $3.75 \mathrm{~mol} \%$. The optimum performance was observed for an AA content of $2.75 \mathrm{~mol} \%$, which corresponded to the maximum theoretical plate value for the separation of DNAs with sizes $\geq 600 \mathrm{bp}$ in the $100 \mathrm{bp}$ DNA ladder. These results demonstrated that even a slight variation in the AA content can significantly affect DNA flow, particularly for $\geq 600 \mathrm{bp}$ DNAs in the $100 \mathrm{bp}$ DNA ladder. The observed trend indicated that the EOF can be controlled by varying the amount of negatively charged AA in the poly(AM-co-AA) coating, which will allow further development of short capillaries for POCT applications.

Acknowledgments: We are grateful to Yoshinori Yamaguchi (Osaka University) for his useful advice and helpful comments. This work was supported by Grants-in-Aid (KAKENHI) for Young Scientists (B) (16K17493, 15K18014) and Scientific Research (B) (17H03209, 15H03827).

Author Contributions: T.N. and Y.H. conceived and designed the experiments; T.N. performed the experiments and analyzed the data; T.N. and Y.H. wrote the paper.

Conflicts of Interest: The authors declare no conflict of interest.

\section{References}

1. Saiki, R.K.; Scharf, S.; Faloona, F.; Mullis, K.B.; Horn, G.T.; Erlich, H.A.; Arnheim, N. Enzymatic amplification of beta-globin genomic sequences and restriction site analysis for diagnosis of sickle cell anemia. Science 1985, 230, 1350-1354. [CrossRef] [PubMed]

2. Mullis, K.; Faloona, F.; Scharf, S.; Saiki, R.; Horn, G.; Erlich, H. Specific enzymatic amplification of DNA in vitro: The polymerase chain reaction. Cold Spring Harb. Symp. Quant. Biol. 1986, 51, 263-273. [CrossRef] [PubMed]

3. Higuchi, R.; Dollinger, G.; Walsh, P.S.; Griffith, R. Simultaneous amplification and detection of specific DNA sequences. Nat. Biotechnol. 1992, 10, 413-417. [CrossRef]

4. Higuchi, R.; Fockler, C.; Dollinger, G.; Watson, R. Kinetic PCR: Real-time monitoring of DNA amplification reactions. Nat. Biotechnol. 1993, 11, 1026-1030. [CrossRef]

5. Furutani, S.; Naruishi, N.; Saito, M.; Tamiya, E.; Fuchiwaki, Y.; Nagai, H. Rapid and highly sensitive detection by a real-time polymerase chain reaction using a chip coated with its reagents. Anal. Sci. 2014, 30, 569-574. [CrossRef] [PubMed]

6. Chen, J.; Ni, Y.; Liu, C.; Yamaguchi, Y.; Chen, Q.; Sekine, S.; Zhu, X.; Dou, X. Rapid identification and quantitation for oral bacteria based on short-end capillary electrophoresis. Talanta 2016, 160, 425-430. [CrossRef] [PubMed]

7. Song, H.-O.; Kim, J.-H.; Ryu, H.-S.; Lee, D.-H.; Kim, S.-J.; Kim, D.-J.; Suh, I.B.; Choi, D.Y.; In, K.-H.; Kim, S.-W.; et al. Polymeric LabChip real-time PCR as a point-of-care-potential diagnostic tool for rapid detection of influenza A/H1N1 virus in human clinical specimens. PLoS ONE 2012, 7, e53325. [CrossRef] [PubMed]

8. Rodriguez-Gonzalez, F.G.; Mustafa, D.A.M.; Mostert, B.; Sieuwerts, A.M. The challenge of gene expression profiling in heterogeneous clinical samples. Methods 2013, 59, 47-58. [CrossRef] [PubMed]

9. Kawai, T.; Naruishi, N.; Nagai, H.; Tanaka, Y.; Hagihara, Y.; Yoshida, Y. Rotatable reagent cartridge for high-performance microvalve system on a centrifugal microfluidic device. Anal. Chem. 2013, 85, 6587-6592. [CrossRef] [PubMed]

10. Botes, M.; de Kwaadsteniet, M.; Cloete, T.E. Application of quantitative PCR for the detection of microorganisms in water. Anal. Bioanal. Chem. 2013, 405, 91-108. [CrossRef] [PubMed]

11. Postollec, F.; Falentin, H.; Pavan, S.; Combrisson, J.; Sohier, D. Advances in quantitative PCR (qPCR) applications in food microbiology. Food Microbiol. 2011, 28, 848-861. [CrossRef] [PubMed]

12. Mitchelson, K.R.; Cheng, J. (Eds.). Capillary Electrophoresis of Nucleic Acids; Methods in Molecular Biology, Volume 163; Humana Press: Totowa, NJ, USA, 2001.

13. Barron, A.E.; Sunada, W.M.; Blanch, H.W. The use of coated and uncoated capillaries for the electrophoretic separation of DNA in dilute polymer solutions. Electrophoresis 1995, 16, 64-74. [CrossRef] [PubMed]

14. Chiari, M.; Cretich, M.; Horvath, J. A new absorbed coating for DNA fragment analysis by capillary electrophoresis. Electrophoresis 2000, 21, 1521-1526. [CrossRef] 
15. Ban, E.; Song, E.J. Capillary electrophoresis methods for microRNAs assays: A review. Anal. Chim. Acta 2014, 852, 1-7. [CrossRef] [PubMed]

16. Sumitomo, K.; Yamaguchi, Y.; Tatsuta, K. RNA separation by in-capillary denaturing polymer electrophoresis with 1,2,5-thiadiazole as an additive. J. Sep. Sci. 2011, 34, 2901-2905. [CrossRef] [PubMed]

17. Liu, C.; Yamaguchi, Y.; Sekine, S.; Ni, Y.; Li, Z.; Zhu, X.; Dou, X. Gene analysis of multiple oral bacteria by the polymerase chain reaction coupled with capillary polymer electrophoresis. J. Sep. Sci. 2016, 39, 986-992. [CrossRef] [PubMed]

18. Chiari, M.; Dell'Orto, N.; Gelain, A. Synthesis and characterization of capillary columns coated with glycoside-bearing polymer. Anal. Chem. 1996, 68, 2731-2736. [CrossRef] [PubMed]

19. Jorgenson, J.W.; Lukacs, K.D. Capillary zone electrophoresis. Science 1983, 222, 266-272. [CrossRef] [PubMed]

20. Hjertén, S. High-performance electrophoresis: Elimination of electroendosmosis and solute adsorption. J. Chromatogr. A 1985, 347, 191-198. [CrossRef]

21. Sumitomo, K.; Sasaki, M.; Yamaguchi, Y. Acetic acid denaturing for RNA capillary polymer electrophoresis. Electrophoresis 2009, 30, 1538-1543. [CrossRef] [PubMed]

22. McCormick, R.M. Capillary zone electrophoretic separation of peptides and proteins using low $\mathrm{pH}$ buffers in modified silica capillaries. Anal. Chem. 1988, 60, 2322-2328. [CrossRef] [PubMed]

23. Bruin, G.J.M.; Chang, J.P.; Kuhlman, R.H.; Zegers, K.; Kraak, J.C.; Poppe, H. Capillary zone electrophoretic separations of proteins in polyethylene glycol-modified capillaries. J. Chromatogr. A 1989, 471, 429-436. [CrossRef]

24. Sumitomo, K.; Mayumi, K.; Minamikawa, H.; Masuda, M.; Asahi, T.; Shimizu, T.; Ito, K.; Yamaguchi, Y. Buffers to suppress sodium dodecyl sulfate adsorption to polyethylene oxide for protein separation on capillary polymer electrophoresis. Electrophoresis 2011, 32, 448-454. [CrossRef] [PubMed]

25. Cobb, K.A.; Dolnik, V.; Novotny, M. Electrophoretic separations of proteins in capillaries with hydrolytically stable surface structures. Anal. Chem. 1990, 62, 2478-2483. [CrossRef] [PubMed]

26. Towns, J.K.; Regnier, F.E. Polyethyleneimine-bonded phases in the separation of proteins by capillary electrophoresis. J. Chromatogr. A 1990, 516, 69-78. [CrossRef]

27. Dougherty, A.M.; Woolley, C.L.; Williams, D.L.; Swaile, D.F.; Cole, R.O.; Sepaniak, M.J. Stable phases for capillary electrophoresis. J. Liq. Chromatogr. 1991, 14, 907-921. [CrossRef]

28. Fujiwara, S.; Honda, S. Determination of cinnamic acid and its analogues by electrophoresis in a fused silica capillary tube. Anal. Chem. 1986, 58, 1811-1814. [CrossRef] [PubMed]

29. Fujiwara, S.; Honda, S. Effect of addition of organic solvent on the separation of positional isomers in high-voltage capillary zone electrophoresis. Anal. Chem. 1987, 59, 487-490. [CrossRef]

30. Lee, C.S.; Blanchard, W.C.; Wu, C.-T. Direct control of the electroosmosis in capillary zone electrophoresis by using an external electric field. Anal. Chem. 1990, 62, 1550-1552. [CrossRef]

31. Hayes, M.A.; Ewing, A.G. Electroosmotic flow control and monitoring with an applied radial voltage for capillary zone electrophoresis. Anal. Chem. 1992, 64, 512-516. [CrossRef] [PubMed]

32. Wu, C.-T.; Lopes, T.; Patel, B.; Lee, C.S. Effect of direct control of electroosmosis on peptide and protein separations in capillary electrophoresis. Anal. Chem. 1992, 64, 886-891. [CrossRef] [PubMed]

33. Sun, P.; Landman, A.; Barker, G.E.; Hartwick, R.A. Synthesis and evaluation of anionic polymer-coated capillaries with $\mathrm{pH}$-independent electroosmotic flows for capillary electrophoresis. J. Chromatogr. A 1994, 685, 303-312. [CrossRef]

(C) 2017 by the authors. Licensee MDPI, Basel, Switzerland. This article is an open access article distributed under the terms and conditions of the Creative Commons Attribution (CC BY) license (http:/ / creativecommons.org/licenses/by/4.0/). 